\title{
研究論文
}

\section{ダイオキシン類発生㧕止・高効率熱回収型小規模産業廃 棄物燃焼排ガス処理システムの開発}

\author{
梁 寛植 $* \cdot$ 金岡千嘉男 $* * \cdot$ 増井 芽 $* * * \cdot$ 加藤 進 $* * * *$
}

\section{要旨}

ダイオキシン類の発生抑止と高効率熱回収を目的とし, 処理能力 $2 \mathrm{t} / \mathrm{day}$ の小規模産業廃棄物熱処理 システムを開発した．本システムの特徵は，ダイオキシン類の再合成に触媒作用する金属類を高温集じ んし, 再合成温度領域でダイオキシン類の再合成を抑止することである，さらに，熱交換器で高効率熱

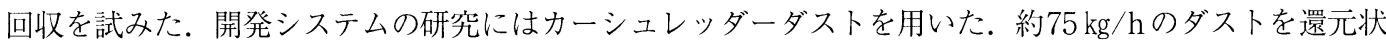
態で熱分解した後，溶融処理することで，約 $90 \%$ のスラグ化率が得られた。また，約 $700{ }^{\circ} \mathrm{C}$ の排ガスを セラミックハニカムフィルターで高温集じんすることで, 熱交換器出口でのダイオキシン類濃度を 1.1ng-TEQ $/ \mathrm{m}_{N}^{3}$ に抑えることができた，さらに，高温集じんによる飛灰の集じん率は約 $98 \%$ \%っった. 特に，触媒重金属類の除去率が高かった．熱交換器による熱回収率は約 $70 \%$ \%あった．以上の結果から 本開発システムは小規模産業廃棄物の焼却処理に多く利用されることが期待できる.

キーワード：小規模産業廃棄物焼却処理システム, ダイオキシン類, 熱分解-溶融炉, 高温集じん, 高効 率熱回収

\section{1.はじめに}

廃棄物の焼却処理は減量化, 無害化などの目的で 多く利用されているが，処理過程で発生するダイオ キシン類が大きな社会問題になり，その発生抑制対 策が求められている。特に, 産業廃棄物は一般廃棄 物の約 8 倍も排出され，その約 4 割が焼却処分され ている．その焼却処理施設数に関する正確な統計は ないが，処理能力 $200 \mathrm{~kg} / \mathrm{h}$ 以下と非常に小規模な施 設で大半が処理されていると言われている。また， その発生量と成分の変動が激しいことと, 炉自体も 不完全燃焼になりやすい構造が多く, 排ガス処理設 備に対しても有害物の発生抑止はともかく, 排出抑 制対策に不完全なものが多いと言われている ${ }^{1)}$.こ のような産業廃棄物の発生特性と焼却炉の構造や排 ガス処理上の問題から小規模焼却施設に対する高濃

*金沢大学大学院 自然科学研究科 Kwan-Sik YANG

**金沢大学工学部 Chikao KANAOKA

***(株アクトリ ムラタ Megumi MASUI

****三重県科学技術振興センター保健環境部 Susumu KATO
度ダイオキシン類の排出が懸念されているが, 十分 な対策が行われていないのが現状である.

一方, ダイオキシン類対策推進基本指針に基づき, ダイオキシン類の排出総量を平成 9 年に比べて 9 割 削減する目標で, 平成 14 年 12 月以降, 処理能力 50 $\mathrm{kg} / \mathrm{h} \sim 200 \mathrm{~kg} / \mathrm{h}$ の小規模焼却施設に対してもダイ オキシン類に係る特定施設及び排出基準により, 厳 しい規制が行われることになっている．規制強化後 には，処理能力の大型化が予想される反面，依然と して小規模焼却施設での処理が大半を占めると予測 される，そこで，小規模でダイオキシン類の生成を 抑制し，新規制值をクリアできる焼却処理システム の開発が緊急の課題である。しかし, 開発に伴い, 処理コストの上昇は避けられない.このためには焼 却処理により最終的に排出される処理生産物が有価 物となる，あるいは有価物とならないまでも処理コ 2001年 7 月 9 日受付 2001年11月 9 日受理 
ストが現在以下となるようなシステムにすることが 重要である。さらに，処理運転コス卜自体も低減で きることが望ましいことは言うまでもない.

ダイオキシン類の発生機構は極めて複雑で，未解 明の部分が多いが，特に，焼却炬内での生成よりは, 排ガス冷却過程で飛灰中重金属類の触媒作用による 生成が大きく寄与すると言われている2-7)。その理 由から，ダイオキシン類生成を抑制するためには再 合成が起こりやすい状態，すなわち，排ガス温度 $250 \sim 400{ }^{\circ} \mathrm{C}$ ，未燃有機化合物の存在，触媒作用の ある重金属類の存在を避けることが重要と考えられ ている。このような焼却処理過程での生成機構を考 えると，発生を抑止するためには燃焼炉による完全 燃焼，再合成温度域より高温でのダス卜中触媒重金 属類の除去が大きなポイントになると思われる。こ 机に対し，廃棄物焼却に扮ける排ガスを高温集じん した事例はいまだそしいが，高温ガスの集じんは石 炭老利用する高効率発電技術の開発に扔いて多く見 られる ${ }^{8,9)}$.この高温集じん法を利用してダイオキ シン類の再合成温度領域 $\left(250 \sim 400^{\circ} \mathrm{C}\right)$ 上り高温で 廃妄物燃焼排ガス中の未燃炭素や触媒金属などが含 まれている飛灰を除去すれば，ダイオキシン類発生 抑止に有效となり,さらに,飛灰が除去されたクリ一 ンな排ガスを高効率で利用できると考えられる ${ }^{10}$.

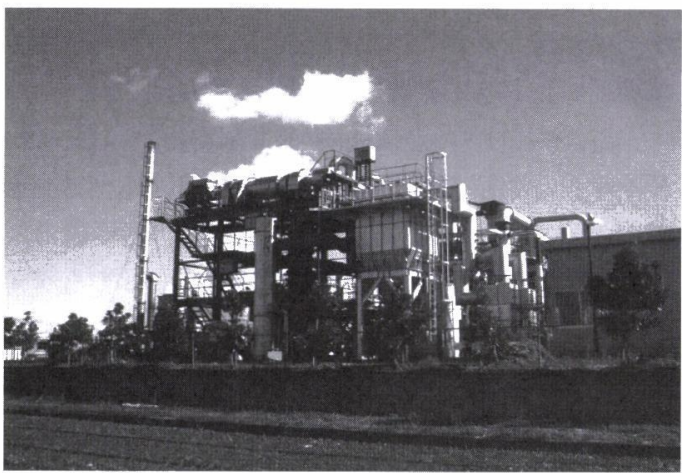

そこで，本研究では高温集じん方法を用いた処理

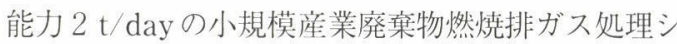
ステムを開発し，システムの性能を評価するための 研究を行った。さらに，兑の実験結果から高温集じ んによるダイオキシン類の生成抑止可能性と高効率 熱利用について検討した。

\section{2. システム開発の基本的な考え方}

システム開発の基本的な考え力は，ダイオキシン 類の再合成に直接関与する物質を高温で除去するこ とで発生を抑止しょうとするものである。さらに, 従来の小規模焼却処理施設の問題点や改良点を考慮 すると，小規模産業廃棄物焼却処理システムとして 以下の項目を満たすことか望ましいと考えられる。 (1)小規模でも産業廃妄物焼却処理を安定に行えるこ と.

(2)再合成を抑止することで，2002年12月から小規模 焼却炉に適用されるダイオキシン類に係わる特定施 設及び排ガス基準值をクリアすること。

(3)再処理が必要な処理生成物が発生しないこと。 (4)排ガスの熱を高効率で利用できること.

このような基本的概念に基づいて開発したシステ ムの全景と構成フローを図ー1に示す。ここで，バ グフィルターは本来のシステム構成には含まれない が，実験条件によっては発生するかもしれないダイ オキシン類を含む有害物質の大気中への排出を防ぐ ため，安全対策として設置したものである。前述の ように焼却処理過程でのダイオキシン類の生成機構 を考えると，発生及び再合成抑止のためには燃焼炉 による完全燃焼，再合成温度域より高温での触媒重 金属類の除去が重要だと思われる。開発システムは これらのことが確実に実現できると考えられる方法 を組み合わせて構成した，各部分の特徵は以下の通 りである。

熱分解炉

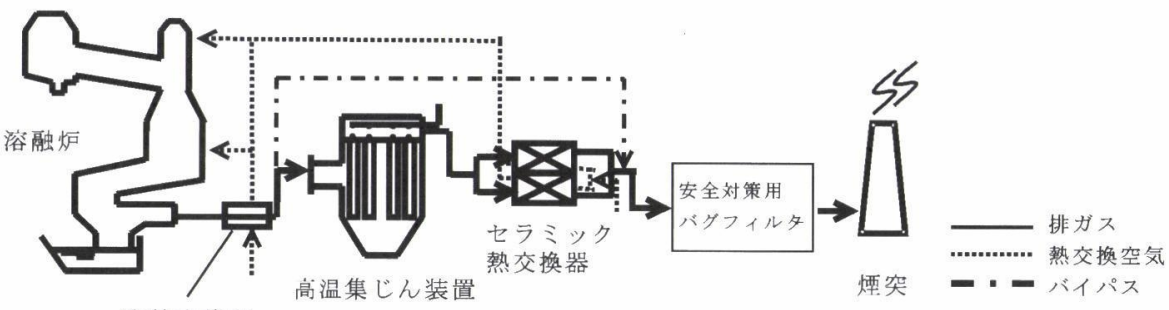

図－1 開発システムの全景と構成フロー 
熱分解は廃棄物をガスとチャーという燃やしやす い燃料に改質することによって，低コストで運転が 可能となる.また，滞留時間が長いため，平均化さ れた熱分解ガスが発生するので処理量, 組成, 発熱 量などの変動に対応が可能であり，コントロールも 容易にできる。

溶融処理は焼却温度より高温で行うため，より完 全燃焼が可能で，幅広いごみ質に対応可能で，廃棄 物中の金属類をスラグとして回収できる。さらに, 空気量が焼却処理より少ないので設備をコンパクト 化できる利点がある。

高温集じんで排ガス中飛扊を再合成温度域より高 温で除去することで，再合成の抑止が可能となり， さらに, 集じん後のクリーンな排ガスの熱を効率よ く利用する上でも効果的である。

熱交換器で熱を回収することで，エネルギー利用 率の向上が可能となる.

本研究では，以下のことを目的とし，開発システ ムの性能評価を行った。

(1)熱分解一溶融処理による産業廃棄物の安全かつ安 定処理.

(2)高温集じん装置による重金属類の除去とダイオキ シン類再合成抑止.

(3)熱交換器による高効率熱回収.

\section{3 . システムの構成と実験方法}

ダイオキシン類発生抑止と高効率熱回収を目的と して開発したシステムは前述のように廃棄物の熱処 理部, 燃焼排ガス処理部, 排ガス冷却部で構成され ており，その各部分の構成と運転方法を以下で説明 する。

本研究で採用した廃棄物の熱処理部は熱分解・溶 融一体型で, 熱分解炉はロータリーキルン方式で,

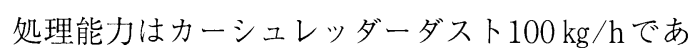
る。熱分解は外部空気と遮断された酸素が少ない還 元状態で, 一次熱交換器からの空気と熱交換器によ る熱回収空気を熱源とし, 間接加熱方式で行った. さらに, 補助バーナーを温度制御用として使用した。 実験ではカーシュレッダーダストの含水率が設計值 より高く, 水分の蒸発により熱を奪われ, 設計值よ りやや少ない $75 \mathrm{~kg} / \mathrm{h}$ で処理した. ダストフィーダ より一定量で供給したダストを約 $350^{\circ} \mathrm{C} て ゙$ 約 30 分か けて熱分解ガスとチャーに分解した後，ともに溶融 炉に供給した。
溶融炉は上部が内径約 $0.65 \mathrm{~m}$ と高さ $3 \mathrm{~m}$ の燃焼部 で，下部が表面溶融タイプで溶融面積が約 $3 \mathrm{~m}^{2}$ の溶 融部になっている．熱処理はカーシュレッダーダス トの持つエネルギーを主な熱源とするが，温度制御 のために補助バーナーを用いた。 ここでは熱分解ガ スを約 $1100{ }^{\circ} \mathrm{C}$ の燃焼部で然焼させ，炉内温度を高 めるとともに, チャーを高温化した後, 約 $1300{ }^{\circ} \mathrm{C}$ で溶融処理し，スラグとして回収した。本研究の主 目的が高温集じんと高効辩熱回収だったので，スラ グの生成方法は構造の簡単な水砕方式を採用した. 溶融炉からの高温燃焼ガスは集じん装置へ送られ る。なおこのとき, 集じん装置入口温度は溶融炉と 集じん装置の間に設置した二重管形式の一次熱交換 器流通冷却空気流量を变化させることによりコント ロールした。ささらに, 集じん装置内の温度コント ロールは, バイパスへの燃焼ガス量をコントロール する設計とした。集じんには材質がコージェライト で耐熱性と熱衝撃性が高いハニカムフィルターを48 本用いた，その一本の外形寸法は一辺が $150 \mathrm{~mm}$ ，長 さが $300 \mathrm{~mm}$, セルピッチが $10 \mathrm{~mm}$ で, 使用されたフィ ルターのトータルろ過面積は約 $46 \mathrm{~m}^{2}$ で, 約 $1 \mathrm{~m} / \mathrm{min}$ のろ過流速で集じんした。さらに，集じんによって フィルター表面に堆積した飛灰の払い落としには, パルスジェット方式を採用した。集じん後の排ガス は下流に設置した熱交換器によって熱回収した。

本研究で使用した熱交換器は蓄熱型で, 材質が コージェライトで耐食性が高いセラミック熱交換器 である. 外形寸法は一辺が $150 \mathrm{~mm}$, 長さが $300 \mathrm{~mm}$ で, 装置は独立した二つの塔をダクトに接続した構造 で，ガス流路を切り換えて運転をするようになって いる. そして, 蓄熱された熱交換器に大気を通し, 熱回収し熱分解炉の熱源として用いることで, 熱工 ネルギーを有効利用できるようにした，熱交換器に よって熱回収した後の排ガスに対しては，有害物質 が大気中に排出されるのを防ぐために設置したバグ フィルターを通して放出した。

\section{4. 実験用ダスト}

本開発システムの処理対象廃棄物として, カー シュレッダーダストを選択した。用いたカーシュ レッダーダストの写真を図ー2に, 性状分析結果を 表 1 に示す ${ }^{11}$ ．金属類に対しては，実験に大きく影 響を及ぼすと考えられる 5 つの成分 $\mathrm{Cu}, \mathrm{Fe}, \mathrm{Al}$,

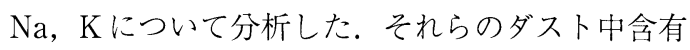


量は上記の並べ順で $5.21 ， 5.39 ， 1.02 ， 0.36$, 0.02wt％だった。通常，カーシュレッダーダストに はウレタン・塩化ビニル・PP · PE等の樹脂類が 多く, 発熱量が高いこと, 金属類(銅線) や各種樹 脂類に含まれる重金属類が多く含まれていると報告 されている ${ }^{12)}$ ままた, ソーダガラスの混人によるア ルカリ成分も多く含まれている。その組成は塩素分 と金属類が多く含まれているため，燃焼過程で高濃 度ダイオキシン類の再合成が予測される。このダス 卜を処理することでシステムの性能，特に高温集じ んによる再合成抑止効果をテストするのに有効だと 考え，処理対象物として採用した。

\section{5 ．測定項目と分析方法}

システム内でのダイオキシンと金属類の挙動を調 べるために，スラグ中の金属類の測定と排ガス中の ダイオキシン類濃度測定及び飛灰中のダイオキシン 類濃度と金属類濃度を测定した。スラグの分析は,

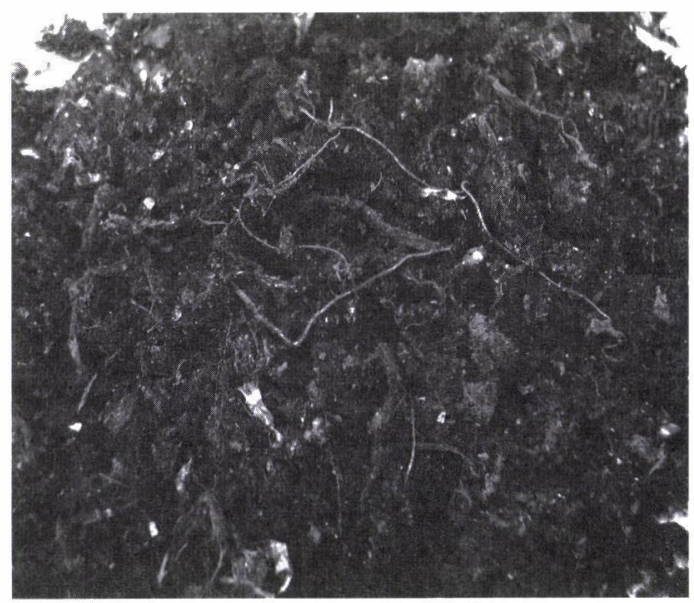

図ー2＼cjkstart実験用カーシュレッダーダスト

表 1 実験用ダストの性状分析結果

\begin{tabular}{|c|c|c|c|c|}
\hline \multirow[b]{2}{*}{ ダ } & \multicolumn{3}{|c|}{ 項 目 } & 分析值 \\
\hline & $\begin{array}{l}3 \\
\text { 成 } \\
\text { 分 }\end{array}$ & $\begin{array}{l}\text { 水分 } \\
\text { 可燃分 } \\
\text { 庅分 }\end{array}$ & $\begin{array}{l}{[\%]} \\
{[\%]} \\
{[\%]}\end{array}$ & $\begin{array}{l}7.66 \\
80.34 \\
12.0\end{array}$ \\
\hline $\begin{array}{l}\text { 卜 } \\
\text { 性 } \\
\text { 状 }\end{array}$ & $\begin{array}{l}\text { 元 } \\
\text { 素 } \\
\text { 組. } \\
\text { 成 }\end{array}$ & $\begin{array}{ll}\mathrm{C} & \text { (炭素) } \\
\mathrm{H} & \text { (水素) } \\
\mathrm{O} & \text { (酸素) } \\
\mathrm{N} & \text { (空素) } \\
\mathrm{S} & \text { (硫黄) } \\
\mathrm{Cl} & \text { (塩素) }\end{array}$ & $\begin{array}{l}\%] \\
{[\%]} \\
{[\%]} \\
{[\%]} \\
{[\%]} \\
{[\%]}\end{array}$ & $\begin{array}{c}48.0 \\
7.0 \\
41.26 \\
1.2 \\
0.04 \\
2.5 \\
\end{array}$ \\
\hline & 発熱量 & 低発熱量 & $\mathrm{cal} / \mathrm{kg}]$ & 約 5000 \\
\hline
\end{tabular}

酸分解 (3HF：1 $\left.\mathrm{HCl} ： 1 \mathrm{HNO}_{3}\right)$ 法により完全溶解し た後, 誘導プラズマ発光分光分析装置 ICP (HITACHI，P-4010S) を用いた. 排ガス中のダイ オキシン類濃度は高温集じん装置入口, 出口と熱交 換器出口で測定した。濃度測定はJIS K 0311の排ガ ス中のダイオキシン類及びコプラナー PCB 測定方 法，そして，集じん灰中のダイオキシン類濃度測定 は厚生省告示 6 号（平成 12 年 1 月 14 日）に基づい て行った。また，高温集じんによる重金属類の除去 性能を調べるため, 集じん装置の入口，出口でJIS Z 8808 ダス卜採取方法の II 型を用いて円筒ろ紙でダ ス卜を捕集した後に硝酸吸収液を入れたインピン ジャーを二連に接続し, 氷冷して採取した。 なお, このときろ紙上に採取された金属を粒子状，吸収瓶 に回収されたものをガス状金属と定義することにし た. 分析はJIS K 0083の排ガス中の金属分析方法に 準拠, ICP-AES法で行った。

\section{6. 実験結果及び考察}

\section{1 システムの運転温度}

システムの運転温度はダイオキシン類の生成抑止 に重要なポイントになる．特に，ダイオキシン類の 再合成を抑止するためには高温集じん装置の運転温 度は重要である，各部分の運転温度を図ー3に示す。 熱分解炉出口の温度は設計值より少し低い約 $330^{\circ} \mathrm{C}$ で運転した。これは，前述のように廃棄物中含水率 が設計值より高く，水分の蒸発により熱を奪われた ためである。また，熱分解ガスを用いた溶融炉では 補助バーナーを用いることで廃棄物の変動量にあま り影響を受けず，約 $1300{ }^{\circ} \mathrm{C} て ゙$ 安定運転した。炉内 の圧力についても, 運転中負圧とした。ささらに, 夕゙ イオキシン類の再合成温度域より高温で飛灰を除去 する高温集じん装置では, 入口温度は溶融炉出口付 近で一次熱交換器による熱回収, さらに，入口でバ イパス量を調節することで設計值に近い温度約 700 ${ }^{\circ} \mathrm{C}$ と湿り排ガス量約 $1200 \mathrm{~m}_{N}^{3} / \mathrm{h}$ で運転ができたが, 出口は約 $500^{\circ} \mathrm{C}$ と, 設計值より約 $100^{\circ} \mathrm{C}$ 近く低い温 度になった。これは，設計段階で集じん扊の付着性 が高いことを想定し，集じん装置下部壁の傾斜角を 大きくとり過ぎたため, 装置内容積が大きくなり, 結果として内部でガス温度の低下が大きくなったと 考えられる，今後の課題として集じん装置内の温度 を均一化する対策は必要と考えられる。そして, 熱 交換器では高温集じん装置出口からの約 $500^{\circ} \mathrm{C}$ の排 


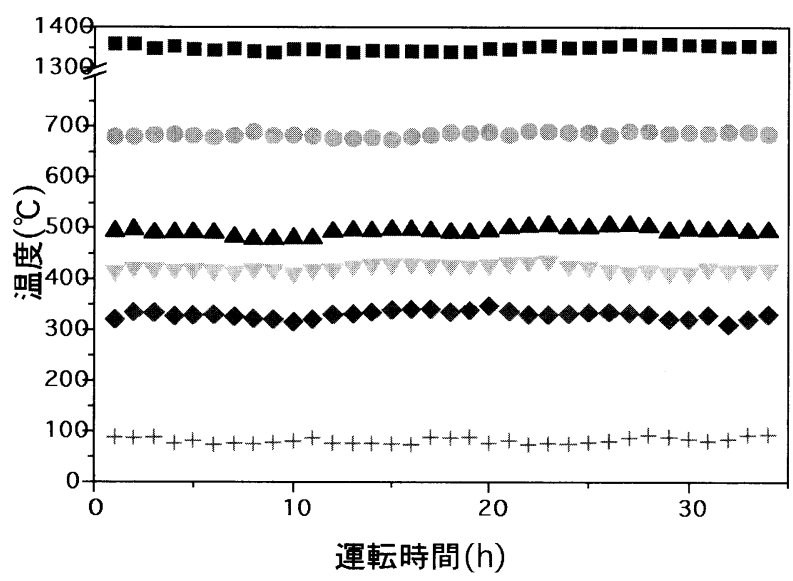

図ー 3 システムの運転温度

\begin{tabular}{c|l} 
表2 & \multicolumn{2}{c}{$\begin{array}{l}\text { スラグの組成 } \\
\text { 分析結果 }\end{array}$} \\
\cline { 2 - 3 } 成分 & $\mathrm{Wt} \%$ \\
\hline $\mathrm{Si}$ & 73 \\
$\mathrm{Na}$ & 6.5 \\
$\mathrm{Fe}$ & 5.3 \\
$\mathrm{Ca}$ & 5.3 \\
$\mathrm{Al}$ & 2.2 \\
$\mathrm{Cu}$ & 2.0 \\
$\mathrm{Zn}$ & 1.2 \\
$\mathrm{Mg}$ & 1.4 \\
$\mathrm{Ti}$ & 0.87 \\
$\mathrm{~K}$ & 0.55 \\
$\mathrm{~Pb}$ & 0.7 \\
$\mathrm{~S}$ & 0.54 \\
$\mathrm{Cr}$ & 0.08 \\
$\mathrm{Mn}$ & 0.09 \\
\hline
\end{tabular}

表 3 スラグの溶出試験結果

\begin{tabular}{|c|c|c|}
\hline 分析項目 & 試験結果 & 土壤環境基淮値 \\
\hline $\mathrm{Hg} \quad[\mathrm{mg} / \mathrm{l}]$ & $<0.0001$ & $\leqq 0.0005$ \\
\hline $\mathrm{Cd} \quad[\mathrm{mg} / \mathrm{l}]$ & $<0.005$ & $\leqq 0.01$ \\
\hline $\mathrm{Pb} \quad[\mathrm{mg} / \mathrm{l}]$ & $<0.005$ & $\leqq 0.01$ \\
\hline $\mathrm{Cr}^{6+}[\mathrm{mg} / \mathrm{l}]$ & $<0.005$ & $\leqq 0.05$ \\
\hline As $[\mathrm{mg} / \mathrm{l}]$ & $<0.001$ & $\leqq 0.01$ \\
\hline $\mathrm{Se} \quad[\mathrm{mg} / \mathrm{l}]$ & $<0.001$ & $\leqq 0.01$ \\
\hline
\end{tabular}

と，これらの結果はスラグの再利用を考慮する上で 有害性に関しては良好と思われる。しかし，今回の 実験では，これ以外のスラグに対するテストは行わ なかったが，今後，燃焼条件によるスラグの組成や 強度など変動を詳しく調べた上で再利用に関する検 討が必要だと考えられる。

\section{3 高温集じんによるダイオキシン類の再合成抑止}

ダイオキシン類の再合成温度領域で集じん温度が 再合成濃度に及ぼす影響を検討するため，集じん温 度を変えて実験を行い，集じん装置入口，出口及び 熱交換器出口の排ガスと飛灰中のダイオキシン類濃 度を測定した．実験は出口の温度を再合成温度より 高温にする運転と入口のバイパス量を変えて集じん 装置に導入される排ガス量を調節することで装置内 の温度を再合成温度域になるようにした実験をし た．その集じん温度とダイオキシン類の再合成濃度 との関係を表 4 に示す．集じん温度の違いによって 熱交換器出口でのダイオキシン類濃度に大きな差が 見られた. 集じん装置出口の温度がダイオキシン類 の再合成温度域の約 $320^{\circ} \mathrm{C}$ で集じんした時，集じん 装置出口のダイオキシン類濃度は $8.3 \mathrm{ng}-\mathrm{TEQ} / \mathrm{m}_{N}{ }_{N}$ と, $0.82 \mathrm{ng}-\mathrm{TEQ} / \mathrm{m}_{N}^{3}$ の集じん装置入口濃度より大 
きく増加した。これに対し，再合成温度域より高温 である約 $500{ }^{\circ} \mathrm{C} て ゙$ 集じんを行った場合は集じん装置 入口の濃度 $0.19 \mathrm{ng}-\mathrm{TEQ} / \mathrm{m}_{N}^{3}$ が集じん装置出口では $0.71 \mathrm{ng}-\mathrm{TEQ} / \mathrm{m}_{N}^{3}$ と若干増加したものの, 約 $320^{\circ} \mathrm{C}$ で集じんを行った時より再合成が抑えられた結果と

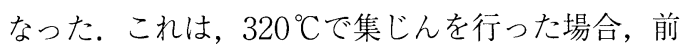
述のように集じん装置内の排ガス温度が再合成温度 域になり，飛灰中重金属類の触媒作用で濃度が増加 したものと考えられる．集じん装置内での排ガスの 滞留時間は運転 1 と 2 ともに約 40 秒程度だった。本 実験では排ガスの滞留時間には大きな差は見られな かったが，滞留時間が長くなると排ガスの温度低下 による再合成濃度の増加や熱回収効率の低下が考え られるので滞留時間を短くする対策が必要である.

そして, 熱交換器出口のダイオキシン濃度は運転 1 と 2 ともに集じん装置出口の濃度より少し増加し たが，再合成が抑えられた結果となった。これは， 高温集じんによって排ガス中の触媒金属類を除去し た結果と考えられる。また，集じん灰中のダイオキ シン類濃度に関しても, 運転 1 が0.0031ng-TEQ/g, 運転 2 が0.0023ng-TEQ/g と, 固相のダイオキシン 類はほとんど存在しなかった。従来焼却システムの ように約 $200^{\circ} \mathrm{C}$ 以下で集じんした場合は，集じん死 中にダイオキシン類が濃縮され，ダイオキシン類の 総量規制により, 再処理が必要となる可能性が高い. しかし, 高温集じんすることで, 集じん扊の再処理 は必要なく, 何よりダイオキシン類の発生総量を減 らすことができる大きなメリットがある。これらの 結果から, 集じん温度はダイオキシン類の再合成濃 度と密接な関係があり, 再合成温度より高温で集じ んすることで，再合成の抑制が可能であることが明 らかになった。しかし，再合成を確実に抑えるため の高温集じんの課題として, 集じん装置出口温度を 再合成温度より高温, 約 $500^{\circ} \mathrm{C}$ 以上に維持すること と, 集じん装置内での排ガス滞留時間を短くする必
要があると考えられる。

\section{4 高温集じんによる重金属類の除去}

溶融炉からの高温然焼ガスに対してハニカムフィ ルターを用いて高温集じんした，集じん装置入口の 排ガス温度とガス量は各々約 $650^{\circ} \mathrm{C}$ と約 $1200 \mathrm{~m}_{N}^{3} / \mathrm{h}$

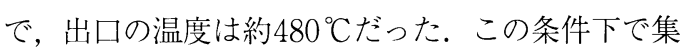
じん装置入口，出口で排ガス中のダストと重金属類 の濃度測定を行い，高温集じんによる除去率を調べ た。さらに，集じん扊中の重金属類濃度を調べた。 その結果を表 5 に示す。多スト濃度は入口が $600 \mathrm{mg} /$ $\mathrm{m}_{N}^{3}$, 出口が $12 \mathrm{mg} / \mathrm{m}_{N}^{3}$ と高温集じんによる除去率は 約 $98 \%$ だった。しかし，集じん装置出口温度が高 い場合，蒸気圧の高い金属塩化物はガス状で排ガス 中に残っているのが確認された．表５の金属類の濃 度は排ガス中のガス状金属類を採取し，フィルター で捕集した粒子状の金属類濃度と合わせたものであ る. 出口の排ガス中ダスト濃度が金属類濃度を合わ せた濃度より低いのは，金属類の濃度にはガス状金 属類濃度が含まれているためである。溶融炉から排 出される排ガス中の重金属類は $\mathrm{Zn}, \mathrm{Cu}, \mathrm{Pb}, \mathrm{Fe}$ が多かった，重金属類別の集じん率を見ると，再合 成の触媒作用が最も強いと言わ机ている $\mathrm{Cu}$ は約 $96 \%$ 除去された。 また，Feと Asの除去率は $98 \%$, 入口濃度が高い $\mathrm{Zn}$ と $\mathrm{Pb}$ は各々 $74,84 \%$ が除去さ れ，出口の濃度は他の物質より高かった，以上の結 果から，再合成に触媒作用が報告されている金属類 の除去率は高いが，蒸気圧の高い金属塩化物の除去 率は低いことがわかった，通常，燃焼排ガス中の重 金属類の存在状態は温度と排ガス組成に大きく影響 される. 高温集じんによる重金属類の除去実験を行っ た時の排ガス中 $\mathrm{HCl}$ の濃度は入口, 出口で各々約 $250 \mathrm{ppm}$ と $50 \mathrm{ppm}$ だった。 それに比べ $\mathrm{SO}_{2}$ 濃度は入口， 出口共に $2 \mathrm{ppm}$ 以下で低かった. 従来の焼却処理シ ステムから発生する $\mathrm{HCl}, \mathrm{SO}_{2}$ 濃度より低い值となっ た. 排ガス中の重金属類が $\mathrm{HCl}$ と反応し, 金属塩化

表 4 集じん温度によるダイオキシン類の濃度変化

\begin{tabular}{lllll}
\hline & & 運転 1 & 運転 2 \\
\hline 集じん装置 & 入口 排ガス温度 $\left({ }^{\circ} \mathrm{C}\right)$ & 750 & 660 \\
& ダイオキシン類濃度 $\left(\mathrm{ng}-\mathrm{TEQ} / \mathrm{m}^{3}{ }_{N}\right)$ & 0.82 & 0.19 \\
\cline { 2 - 5 } & 出口 排ガス温度 $\left({ }^{\circ} \mathrm{C}\right)$ & 320 & 500 \\
& ダイオキシン類濃度 $\left(\mathrm{ng}-\mathrm{TEQ} / \mathrm{m}^{3}{ }_{N}\right)$ & 8.3 & 0.71 \\
\cline { 2 - 5 } 熱交換器 & 飛灰中ダイオキシン類濃度 $(\mathrm{ng}-\mathrm{TEQ} / \mathrm{g})$ & 0.0031 & 0.0023 \\
\cline { 2 - 4 } & 出口 排ガス温度 $\left({ }^{\circ} \mathrm{C}\right)$ & 40 & 110 \\
& ダイオキシン類濃度 $\left(\mathrm{ng}-\mathrm{TEQ} / \mathrm{m}^{3}{ }_{N}\right)$ & 9.6 & 1.1 \\
\hline
\end{tabular}


表 5 高温集じんによる重金属類の除去

\begin{tabular}{lccc}
\hline & 集じん装置入口 & 集じん装置出口 & 集じん灰 $(\mathrm{mg} / \mathrm{kg})$ \\
\hline 湿り排ガス $\left(\mathrm{m}^{3} / \mathrm{h}\right)$ & 1200 & 818 & - \\
排ガス温度 $\left({ }^{\circ} \mathrm{C}\right)$ & 650 & 480 & - \\
$\mathrm{H} 2 \mathrm{O}(\%)$ & 6.5 & 6.0 & - \\
$\mathrm{O}_{2}(\%)$ & 10.0 & 11.8 & - \\
$\mathrm{CO}(\%)$ & 7.1 & 5.6 & - \\
ダスト濃度 $\left(\mathrm{mg} / \mathrm{m}_{N}{ }^{3}\right)$ & 600 & 12 & - \\
$\mathrm{Zn}\left(\mathrm{mg} / \mathrm{m}_{N}{ }^{3}\right)$ & 160 & 42 & 390000 \\
$\mathrm{Cu}\left(\mathrm{mg} / \mathrm{m}_{N}^{3}\right)$ & 55 & 2.4 & 110000 \\
$\mathrm{~Pb}\left(\mathrm{mg} / \mathrm{m}_{N}^{3}\right)$ & 44 & 7.2 & 2400 \\
$\mathrm{Fe}\left(\mathrm{mg} / \mathrm{m}_{N}^{3}\right)$ & 4.4 & 0.097 & 16000 \\
$\mathrm{Cr}\left(\mathrm{mg} / \mathrm{m}_{N}^{3}\right)$ & 0.14 & 0.044 & 270 \\
$\mathrm{Cd}\left(\mathrm{mg} / \mathrm{m}_{N}^{3}\right)$ & 0.12 & 0.075 & 38 \\
$\mathrm{As}\left(\mathrm{mg} / \mathrm{m}_{N}^{3}\right)$ & 0.042 & $<0.001$ & 10 \\
$\mathrm{Ti}\left(\mathrm{mg} / \mathrm{m}_{N}^{3}\right)$ & 0.044 & 0.0036 & 4 \\
$\mathrm{Hg}\left(\mathrm{mg} / \mathrm{m}_{N}^{3}\right)$ & 0.03 & 0.012 & $<0.01$ \\
\hline
\end{tabular}

物になると蒸気圧が高くなり気化しやすくなるの で，高温域での集じんは難しくなると考えられる。

今回の実験では集じん装置入口で非常に少なかっ た粒子状の金属塩化物が出口で増加した結果が得ら れた。これは蒸気圧の高い金属塩化物が高温の集じ ん装置上流ではガス状で存在し，フィルターを通り 抜けた後, 排ガス温度の低下により，固化したもの と考えられる，さらに，溶融処理により発生したガ ス状成分がフィルターを通り抜けるのを考虑し, フィ ルター表面に堆積するダスト層を厚くした. しかし， それはダストがフィルター表面で排ガス $($ 特に $\mathrm{HCl}$ ) と反応する時間を与えた結果となり，ダストがガス 状になりフィルターを通り抜けたとも考えられるの で，今後，高温での排ガス組成が重金属類の存在状 態に及ぼす影響を検討し集じん効率を向上させる必 要があると考えられる。

\section{7. システムとしての総合評価}

ダイオキシン類の発生抑止にはダイオキシン類の 二次生成が起こりやすい状態，すなわち，排ガス温 度 $250 \sim 400{ }^{\circ} \mathrm{C}$, 未燃有機化合物の存在, 触媒作用 のある重金属類の存在を避けることが重要である. そのためには燃焼炉による完全燃焼, 高温集じんに よる重金属ダストの除去が大きなポイントになる が，本排ガス処理システムはこれらのポイントを充 分に満足すると言える.

従来，ダイオキシン類の排出抑制は，焼却システ ム中で生成したダイオキシン類をバグフィルター単 独あるいは活性炭などと組み合わせて捕集する方法 がとられてきた，それと比べると本開発システムは
ダイオキシン類の再合成に直接関与する物質を高温 で除去することにより発生を抑止しようとするもの である. 本研究では高温集じん装置を約500～700 ${ }^{\circ} \mathrm{C}$ で運転したが，出口温度が高いほどダイオキシン 類の濃度が低くなる傾向が見られたので，高温集じ んはダイオキシン類の発生抑止に有効であることが 確認できた。しかし，溶融炉出口でかなり低かった ダイオキシン類の濃度が集じん装置出口では若干高 くなった。今回の研究では, 設計段階で集じん死の 付着性が高いことを想定し，集じん装置下部壁の傾 斜角を大きくとり過ぎたため, 装置内容積が大きく なった。その結果として集じん装置内部で予想以上 の排ガス温度の低下を招いた可能性があるので，さ らに詳細な検討が必要である。

しかし，ダイオキシン類が発生しやすい成分を多 く含むカーシュレッダーダストを処理対象物とした ことと設計上の䛊りがあったにもかかわらず，前述 のような研究成果が得られたのはシステムの性能を 評価するのに良好な結果と考えられる。今後, 本排 ガス処理システムは小規模産業廃棄物焼却処理にお けるダイオキシン類の発生抑止と高効率熱回収方法 として大いに利用されることが期待できる.

\section{8. まとめ}

小規模産業廃棄物の安全かつ安定的な処理のため に高温集じん法を用いた産業廃棄物燃焼排力゙ス処理 システムを開発し，カーシュレッダーダストを用い て実験を行った．本実験で得られた成果をまとめる と以下のとおりである.

1. 小規模産業廃棄物の焼却処理に熱分解-溶融炉 
を用いることで安全かつ安定的処理ができた．

2. 廃棄物の安定的な減量化と金属類を再処理が不 要な安全なスラグとして回収できた。

3. ダイオキシン類の再合成温度より高温で触媒金 属類を高効率で除去できた。

4. 高温集じんにより，ダイオキシン類の再合成を 抑止し，2002年12月から適用されるダイオキシ ン類の基準值をクリアできた。

5. 高温集じん後のクリーンな排ガスを熱交換器よ り高効率で熱回収できた。

謝辞：本研究はエネルギー・産業技術総合開発機構 (NEDO) 平成10年度 3 次補正予算「即効型地域 ンソーシアム」の一環として行ったものである。こ こに記して，感謝を示します。

\section{参考文献}

1 ）三好 康彦：小型燒却炉選定と維持管理，公害対策技術 同好会

2 ) W. M. Shaub et al., : Dioxin formation in incinerators, Environ. Sci. Technol, Vol.17, pp.721-730 (1983)

3 ) F. W. Karasek, L. C. Dickson : Model studies of polychlorinated dibenzo-p-dioxins formation during municipal refuse incineration, Science, 237 (4816), pp.754-762
(1987)

4 ) L. Stieglitz, H. Vogg : On the formation conditions of $\mathrm{PCDD} / \mathrm{PCDF}$ in fly ash from municipal waste incinerators, Chemosphere, 16 (8), pp.1917-1922 (1987)

5 ) L. Stieglitz, G. Zwick, J. Beck, W. Roth, H. Vogg : On the de-nove synthesis of PCDD/PCDF on fly ash of municipal waste incinerators, Chemosphere, 18 (1), pp.1219-1266 (1989)

6 ) Kees Olie, Ruud Addink, Mirjam Schoonenboom : Metals as catalysts during the formation and decomposition of chlorinated dioxins and furans in incineration processes, J. Air \& Waste Manage. Assoc, Vol.48, pp.101-105 (1998)

7 ) Moo Been Chang, Tsai Fei Huang: The effects of temperature and oxygen content on the PCDD/PCDFs formation in MSW fly ash, Chemosphere, Vol.40, pp159-164 (2000)

8 ) (株) 日本粉体工業技術協会編：粉塵の技術と装置, 日本 工業新聞社, pp.183-202 (1997)

9 ) 金岡千嘉男：石炭灰の高温分離技術の動向, 日本エネル ギー学会誌, 77 (851), pp.170-176 (1998)

10）金岡千嘉男，梁 寛植：高温集じん法利用による粒子お よび有害ガスの除去，金属，68 (9)，pp.6-13 (2000)

11) 平成 10 年度地域コンソーシアム研究開発事業：ダイオキ シン発生抑止・高効率熱回収型産業廃棄物用焼却排ガス 処理システムの構築, 成果報告書

12）飯田修司：自動車シュレッダーダストの減容乾留実証プ ラント，資源と環境，9(2), pp.49-58 (2000)

\title{
Development of a Small-scale Industrial Waste Combustion Flue Gases Treatment System for Prevention of Dioxin Formation and High-Efficiency Heat Recovery
}

\author{
Kwan-Sik Yang, Chikao Kanaoka, Masui Megumi, Kato Susumu
}

\begin{abstract}
We developed a small-scale industrial waste combustion flue gas treatment system operating at a capacity of $2 t /$ day, for the purpose of suppression of dioxin formation and high-efficiency heat recovery. The feature of this system resides in hot gas cleaning of metals catalytically acting in re-formation of dioxins and rapid cooling of the flue gas in a re-formation temperature region. In addition, for a high-efficiency heat recovery was accomplished with a heat exchanger. Car shredder dust was selected to test the newly developed system. The dust was thermally decomposed under the reduced condition at $75 \mathrm{~kg} / \mathrm{h}$, and thereafter subjected to melting treatment, whereby giving a slag formation ratio of about $90 \%$. Furthermore, ca. $700{ }^{\circ} \mathrm{C}$ flue gas was subjected to hot gas cleaning with a ceramic honeycomb filter, whereby the dioxin concentration could be controlled to $1.1 \mathrm{ng}-\mathrm{TEQ} / \mathrm{m}^{3}$ at the outlet of the heat exchanger. The dust collection ratio of the scattered ash by means of hot gas cleaning was about $98 \%$, and a removing rate of a heavy metal catalyst was especially high. The heat recovery efficiency with the heat exchanger was about $70 \%$. From the above results, this newly developed flue gas treatment system can be widely utilized for a small-scale industrial waste treatment.

Key Words : small-scale industrial waste combustion flue gas treatment system, dioxin, gasifying-melting furnace, hot gas cleaning, high-efficiency heat recoverysmall.
\end{abstract}

